Stephen V. Tracy

Athenian Lettering of the Fifth Century B.C. 

Stephen V. Tracy

\section{Athenian Lettering of the Fifth Century B. C.}

The Rise of the Professional Letter Cutter 
ISBN 978-3-11-040142-4

e-ISBN (PDF) 978-3-11-040759-4

e-ISBN (EPub) 978-3-11-040763-1

Library of Congress Cataloging-in-Publication Data

A CIP catalog record for this book has been applied for at the Library of Congress.

Bibliographic Information published by the Deutsche Nationalbibliothek

The Deutsche Nationalbibliothek lists this publication in the Deutsche Nationalbibliografie; detailed bibliographic data are available on the internet at http://dnb.dnb.de.

(C) 2016 Walter de Gruyter GmbH, Berlin/Boston

Typesetting: Dörlemann Satz GmbH \& Co. KG, Lemförde Printing and binding: Hubert \& Co. GmbH \& Co. KG, Göttingen

$\otimes$ Printed on acid-free paper

Printed in Germany

www.degruyter.com 
For June Allison and Christian Habicht with gratitude

In memory of

Sterling Dow and Eugene Vanderpool 
